\title{
Coğrafi Bilgi Sistemleri İle Orman Yangını Risk Haritası Oluşturulması: Ören Örneği
}

\author{
Mehtap ÖZENEN KAVLAK ${ }^{1 \star}$, Adem KURTIPEK ${ }^{1}$, Saye Nihan ÇABUK ${ }^{1}$
}

Öz

Orman yangınları çevre için büyük bir doğal afettir. Her yıl hem doğal hem de insan faktörü sonucu pek çok orman yangını meydana gelmekte, doğal ve kültürel çevre bu yangınlardan olumsuz etkilenmektedir. Çalışma alanı olan Kütahya bölgesi ele alındığında; 2005-2009 yılları arasında toplam 128 adet yangının çıktığı ve toplam 99,18 hektar alanın zarar gördüğü belirlenmiştir. Bu çerçevede, çalışmanın amacı Kütahya - Ören Orman İşletme Şefliği örneğinde orman yangını riskinin coğrafi bilgi sistemleri (CBS) olanakları kullanılarak belirlenmesidir. Böylelikle oluşabilecek yangınlara hazırlıklı olunması, yangından kaynaklanan risklerin asgari düzeye indirilmesi ve yangınların neden olduğu gerek maddi gerek fiziksel zararların önlenmesine katkı sağlanması hedeflenmiştir. Bu bağlamda, çalışma alanına ait CBS destekli yangın risk haritası oluşturulmuştur. Ayrıca bölgede yer alan yangın kulelerinin, çalışma alanın ne kadarına hakim olduğu da görülebilirlik analizi ile belirlenmeye çalışılmıştır. CBS ortamında elde edilen görülebilirlik analizi ve yangın risk haritaları sonuçlarına göre tehlike ve risklerin önlenmesine yönelik önerilerde bulunulmuştur.

Anahtar Kelimeler: CBS, Orman, Orman yangını, Yangın risk haritası, Ören Orman İşletme Şefliği

\section{The Development of Forest Fire Risk Maps Using Geographical Information Systems Capabilities for Ören Forest Management Unit - Kütahya}

\section{ABSTRACT}

Forest fires are major natural disasters for the environment. Many forest fires occur every year due to both natural and anthropogenic factors, resulting in important negative impacts on the natural and cultural environment. Considering the Kütahya region, which is the study area; it was determined that a total of 128 fires broke out and 99,18 hectares were damaged between 2005 and 2009. Within this frame, the aim of this study is to determine the forest fire risks within Ören Forest Management Unit - Kütahya, using geographical information systems (GIS) capabilities. Thus, the targets of the study are to provide preparedness against potential forest fires, minimize the forest fire risks and contribute to the prevention of both financial and physical damages resulting from forest fires. To fulfill the mentioned aim and the targets, a GIS-aided fire risk map was developed for Ören Forest Management Unit - Kütahya. In addition to this, the coverage area of the existing fire towers within the study area was evaluated through visibility analysis. Considering the results of the visibility

\footnotetext{
${ }^{1}$ Yer ve Uzay Bilimleri Enstitüsü, Uzaktan Algılama ve Coğrafi Bilgi Sistemleri Anabilim Dalı, Eskişehir Teknik Üniversitesi, Eskişehir,

*ilgili yazar / Corresponding author: mehtapozenen@eskisehir.edu.tr

Gönderim Tarihi / Received Date: 29.07.2019

Kabul Tarihi / Accepted Date: 29.05.2020
} 
analysis and the forest fire risk map created in the GIS environment, suggestions were made for the mitigation of the fire hazards and risks.

Keywords: GIS, Forest, Forest fire, Forest fire risk mapping, Oren Forest Management Unit

\section{GíRiş}

Ormanlar, gerek doğal dengenin korunmasında gerekse insan yaşantısında çok önemli bir yere sahiptir (İşçi, 2018). Her yıl çeşitli nedenlerden dolayı çıkan, çoğunun nedeni belirlenemeyen ve artarak devam eden orman yangınları dönüşü olmayan zararlara yol açmaktadır (Modugno, Balzter, Cole ve Borrelli, 2016; Nasi, Dennis, Meijaard, Applegate ve Moore, 2002; Patz, Frumkin, Holloway, Vimont ve Haines, 2014; Siachalou, Doxani ve Tsakiri-Strati, 2009). Orman yangınları insan faktörlü (dikkatsizlik, ihmal veya kasten) ya da doğa olayları (yıldırımlar, vs.) sonucu meydana gelen yangınlar olarak sınıflandırılabilir. Olası bir orman yangınında doğal döngüyü durdurmak mümkün değildir. Ancak çeşitli yöntemler ile bu döngünün zararlarını en aza indirmek veya önlemek mümkündür.

Orman yangınlarının oluşması için üç faktörün bir arada bulunması gereklidir. Bunlar; yanıcı madde, oksijen ve tutuşma sıcaklığıdır. Bu faktörlerden birisi bulunmadığında ya da yeterli olmadığında yangın çıkmamaktadır (Bailey, 2001; Kaysis, 2019; Peker ve Atılgan, 2015). Ayrıca nisbi nemin saat 10.00 'da $\% 40$ ve $\% 40$ 'dan daha düşük olması, yine nem oranının 12 saat gibi kısa bir zaman diliminde \% 20'den fazla düşüş göstermesi durumlarında yangın riski artmaktadır. Rüzgâr hızının 20 km/saat ve üzerinde oluşu, kurak geçen yaz günleri gibi olağanüstü hava koşulları yangının şiddetini arttırmaktadır (Finney, 2005; Kaysis, 2019). Bununla birlikte, insan faaliyetlerinin ormanların tutuşma dağılımı üzerindeki etkisini anlamak, tutuşma riskinin yönetilmesi ve azaltılması için merkezi bir öneme sahiptir. Bir yangının söndürülmesi için, yangın küçük çapta iken erken müdahale edilmesi gerekmektedir. Yangınla mücadele kaynaklarının ise en riskli bölgelerin yakınına yerleştirilmesi hayati önem taşımaktadır (Romero-Calcerrada, Novillo, Millington ve Gomez-Jimenez, 2008).

Orman yangınları risk derecelerine göre beş grupta incelenmektedir (Orman Genel Müdürlüğü, 1995):

1.Derece / Yangına en çok riskli grup için: Yılda 10,1 adet ve daha fazla orman yangını çıkan Orman İşletmeleri

2.Derece / Yangına çok riskli grup için: Yılda 6,1-10,0 adet orman yangını çıkan Orman İşletmeleri

3.Derece / Yangına orta riskli grup için: Yılda 3,1-6,0 adet orman yangını çıkan Orman İşletmeleri

4.Derece / Yangına az riskli grup için: Yılda 1,1-3,0 adet orman yangını çıkan Orman İşletmeleri

5.Derece / Yangına çok az riskli grup için: 1,0 adet ve daha az orman yangını çıkan Orman İşletmeleri.

Orman yangınlarının risk derecesini etkileyen sebepler ise aşağıda özetlenmiştir (Orman Genel Müdürlüğü, 1995):

- Bütünlük gösteren, 0.7 ve daha fazla kapalıııta, yanıcı madde içeren alanlar

- Güney, güneybatı ve batıya bakan alanlar

- \%60 dan fazla eğime sahip alanlar

- Dar dere, kuru dere yapısına sahip alanlar

- Gençleştirme dikimi yapılan alanlar.

Türkiye illere göre orman yoğunluğu haritası Şekil 1 'de, Türkiye geneli orman yangını risk haritası ise Şekil 2'de yer almaktadır. Buna göre Kütahya ili Türkiye genelinde 1. dereceden 
yangına hassas bölgeler içerisinde yer almaktadır. Kütahya ili bünyesinde 6 adet bölge barındırmaktadır. Bunlardan Simav, Tavşanlı, Gediz, Kütahya bölgeleri 1. derece, Emet 2. derece ve Domaniç ise 3 . dereceden yangına hassas bölgelerdir.

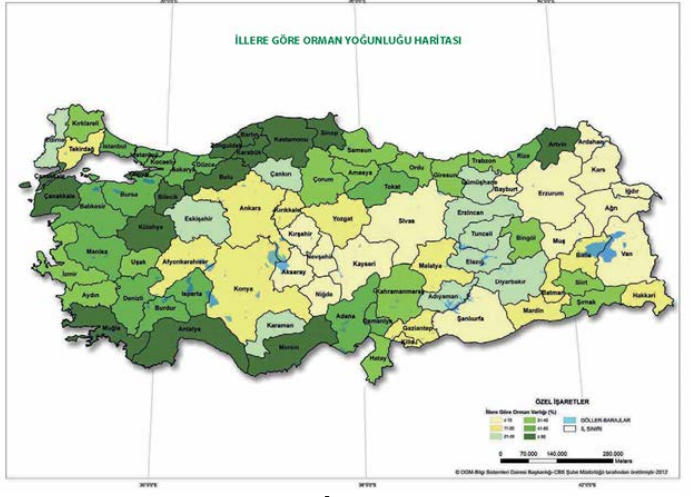

Şekil 1. Türkiye İllere Göre Orman Yoğunluğu Haritası (Orman Genel Müdürlüğü)

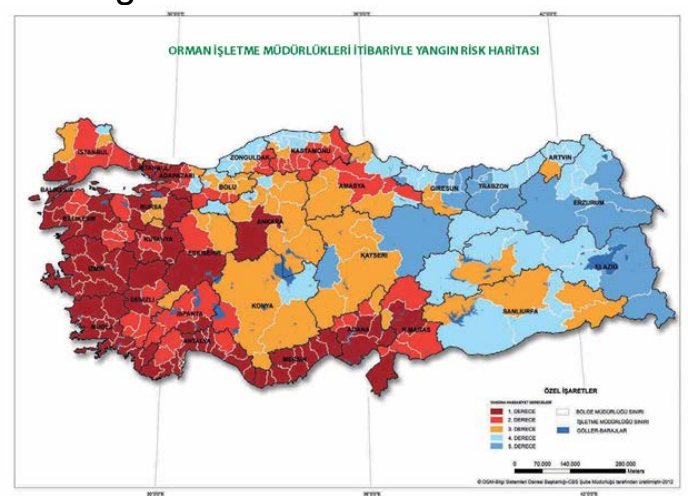

Şekil 2. Orman İşletme Müdürlükleri İtibariyle Yangın Risk Haritası (Orman Genel Müdürlüğü)

Bu çalışma, Kütahya ili, Kütahya Orman İşletme Müdürlüğü, Ören Orman İşletme Şefliğini kapsamaktadır. Çalışmanın amacı ise CBS teknolojileri ile bölgeye ait sayısal haritalar kullanılarak Ören Orman İşletme Şefliği için orman yangınları risk haritasının hazırlanması, ayrıca bölgede bulunan yangın kulelerinden alanın ne kadarının görülebildiğinin saptanmasıdır. CBS'nin gelişmiş analiz yetenekleri ile olası orman yangınlarının önlenmesi ve oluşmuş yangınlara da en kısa zamanda müdahalede büyük bir atılım sağlanacaktır.

$\mathrm{Bu}$ kapsamda, çalışma yapılmadan önce öncelikle literatürde bu konu ile ilgili olarak gerçekleştirilen çalışmalar incelenmiştir. Bu çerçevede yapılan araştırmalardan biri Çanakkale, Ecebat bölgesinde uzaktan algılama ve CBS teknolojisi kullanılarak orman yangınları risk haritası oluşturulması çalışmasıdır (Erten, Kurgun ve Musaoglu, 2004). Benzer bir çalışma da Hindistan, Gorna Nadi bölgesi için hazırlanan orman yangınları risk haritasıdır (Jaiswal, Mukherjee, Raju ve Saxena, 2002). Massada, Radeloff, Stewart ve Hawbaker (2009) yangın riskini analiz etmek için girdi olarak yakıt ve topografya girdilerini, hava durumu verilerini ve yapı verilerini incelemişlerdir. Öte yandan, Chuvieco ve Salas (1996) yangın tehlikesi endeksini tahmin etmek için yakıt tipi, sıcaklık, nem, kompaktlık, bitki nemi, topografya ve insan aktivitesini dikkate almışlardır. Kızılçam Korudağ bölgesi için ise yangın davranışının haritalanması gerçekleştirilmiştir (Küçük ve Bilgili, 2007). Ayrıca, CBS tabanlı bir yangın simülasyon modellemesi yapılmıştır. Böylece gerçekleştirilen üç senaryo ile yangın risk haritaları oluşturulmuştur (Yassemi, Dragićević ve Schmidt, 2008). Çalışkan ve Boydak (2017) yarı kuraklıktaki ağaçlandırma faaliyetlerinin bir değerlendirmesini gerçekleştirmişlerdir. MBir başka çalışmada ise, farklı ağaç tiplerinin yangınlara farklı tepkiler verdiği belirlenmiş ve çıkan yangınların sonuçları ele alınmıştır (Shafiei, Akbarinia, Jalali ve Hosseini, 2010). Yanıcı madde durumunun yangınlar üzerindeki etkilerinin, yanıcı madde haritaları ile belirlendiği çalışmalar da literatürde yer almaktadır (Küçük ve Bilgili, 2007; Küçük, Bilgili ve Durmaz, 2005). Bingöl (2017) tarafından yapılan çalışmada yola ve yerleşime olan mesafe, bakı, eğim ve vejetasyon türü parametreleri değerlendirilerek Burdur ilinin yangın risk haritasının hazırlanması amaçlanmıştır. Çalışmada CBS bu parametrelerle ilgili olarak gerekli olan analiz ve hesaplamaları geçekleştirmek için kullanılmıştır. Orman yangını üzerinde etkili olan kriterlere subjektif ağılıklar atanarak yapılan bu çalışma sonucunda elde edilen yangın risk haritasına göre alanın \%12,3'ü çok riskli, \%20,2'si riskli, \%20'si orta riskli, \%31,5'i düşük riskli, \%16'sı ise risksiz olarak belirlenmiştir. Asri, Çorumluoğlu ve Özdemir (2017) Antalya ve yöresi için yaptıkları çalışmada özellikle sıcaklık, nem, rüzgâr ve topoğrafya açısından verileri analiz ederek bölgeye ait önceki yangınlarla ilişkili risk haritası oluşturmuşlardır. Bölgedeki orman dağılımının yoğun olduğu güney 
bakıdaki dağ yamaçlarında ve sahile yakın düşük kotlu vadilerde yangın çıkışında en etkili faktörün nispi nem olduğu tespit edilmiştir. Sahile paralel uzanan dağ yamaçları ile Antalya ilinin yer aldığı orta kısımdaki ovanın her iki kenarından içe doğru uzanan dağ yamaçlarında da yine yangın çıkışı açısından en önemli ve en baskın faktörün düşük nem olduğu ve yangın çıkışında ikincil derecede etkin olan faktörün ise hava sıcaklığı olduğunu belirlenmiştir. Ayrıca paralel olarak uzanan bu dağların arkasındaki yüksek düzlüklerde orman yangını çıkışında etkin faktörün artık nispi nem değil de özellikle hava sıcaklığı ve rüzgâr olarak ortaya çıktığını ortaya koymuşlardır. Eugenio vd. (2016) tarafından CBS kullanarak bir orman yangını riski haritası hazırlamak için istatistiksel bir model geliştirilmiştir. Özşahin (2014) tarafından yapılan çalışmada Antakya Orman İşletme Müdürlüğü sınırları dahilinde orman yangını riskini etkileyen faktörler (yükselti, eğim, bakı, yerleşmeye mesafe, yol hatlarına mesafe, arazi kullanımı, bitki örtüsü) ile yangına müdahaleyi etkileyen faktörler (su kaynaklarına mesafe, yangın müdahale ekiplerine mesafe, yangın gözetleme kulelerine mesafe, yangın gözetleme kulelerinden görülebilirlik) göz önünde bulundurularak CBS teknikleri ile AHS (Analitik Hiyerarşi Süreci) yöntemi kullanarak analiz edilmiştir ve orman yangını duyarlıık analizinin gerçekleştirilmesi amaçlanmıştır. Çalışmada, inceleme alanında orta duyarlı alanların egemen olduğu ve sahanın orta derecede bir orman yangını potansiyeli barındırdığı belirlenmiştir. Orman yangını duyarlıı̆ı daha çok Amanos Dağları'nın kuzey kesimi, Antakya'nın kuzeybatı kesimi, Kuseyr Platosu ve Reyhanlı çevresinde görülmektedir. $\mathrm{Bu}$ çalışma ile CBS, orman yangını planlamalarında etkin karar vermeye yardımcı araç olarak kullanılabileceğini göstermiştir. Van Wagtendonk, Root ve Key (2004) çalışmalarında uzaktan algılama kullanarak yanma şiddeti hakkındaki verileri karşılaştırmışlardır. Meddens, Kolden ve Lutz (2016) ise LANDSAT uydu görüntülerinden faydalanarak orman yangınının çevresindeki alanlarda bulunan yanmamış bölgeleri sınıflandırmak için bir model geliştirmişlerdir. Navarro vd. (2017) tarafından gerçekleştirilen çalışma Madeira yangınlarının yanma şiddetini değerlendirmek için çeşitli spektral endekslerin değerlendirilmesinin ön sonuçlarını sunmaktadır. Yangının şiddeti, yangın aralığı ve bakı (eğim yönelimi) etkileri Kavgaci, Örtel, Torres ve Safford (2016) tarafından irdelenmiştir. White, Ryan, Key ve Running (1996) bitki örtüsünü incelemek ayrıca farklı yanık şiddeti olan alanları tespit etmek ve bu yanık bölgelerdeki spektral değişiklikleri değerlendirmek için uzaktan algılama kullanmışlardır. İnsan kaynaklı yangınların batı İran'daki Zagros Dağlarında toprağın çeşitli bileşenleri üzerindeki etkileri Mirzaei (2016) tarafından araştırılmıştır.

Orman yangınlarının başlaması ve yayılması üzerinde çok farklı etmen mevcuttur. CBS ile dinamik olmayan faktörleri (iklimsel faktörler dışında kalan insan faktörü, meşcere özellikleri ve topografya ile ilgili veriler) kullanılarak, her katmanı kendi ağırık puanı ile aynı zamanda değerlendirmek ve bir yangın risk haritası oluşturulabilmek mümkün olmaktadır. Literatür incelendiğinde farklı kriterler ve yöntemler kullanılarak gerçekleştirilen orman yangını risk haritalarının mevcut olduğu görülmektedir. Ancak Kütahya Ören Orman İşletme Şefliği için CBS imkanları veya başka yöntemlerle gerçekleştirilen herhangi bir yangın risk haritasının bulunmadığı dikkat çekmektedir. Ören İlçesi'nin orta yangın riski olan alanları yaygın bir şekilde kapsaması ayrıca orman yangınlarıyla mücadele için koruyucu önlemleri gerekli kılmaktadır. Ayrıca bölgede gerçekleşen yangınların konum bilgilerine tam olarak ulaşılamamış olup bu da ayrıca bir çalışma gerektirmektedir. Bu kapsamda, bu çalışmada CBS teknolojileri kullanılarak, çalışma alanına ait orman yangını risk haritası oluşturulmuştur.

\section{MATERYAL VE YÖNTEM}

Orman yangınlarını etkileyen birçok faktör bulunmaktadır. Bu faktörler; orman meşcere tipi, yerleşim yerlerine ve yollarına olan mesafe ve bölgenin topoğrafik özellikleri olarak sınıflandırılabilir. Kütahya Orman İşletme Müdürlüğü, Ören Orman İşletme Şefliği için ilgili faktörler ilerleyen bölümlerde yer almaktadır. 


\section{1. Çalışma alanı ve çalışma materyali}

Kütahya Orman İşletme Müdürlüğü 1943 yılında kurulmuş olup, Ege Bölgesinin iç kısmında Kütahya ili sınırları içerisinde yer almaktadır. Toplamda 413.176 hektar sorumluluk alanına sahip bu işletmenin \% 51'ini (209.052 ha) ormanlık alanlar, \% 49' unu ise (204.124 ha) açıklık alanlar oluşturmaktadır. Ormanlık alanın \% 58 'i (121.897 ha) normal koru, \% 42'si (87.155 ha) bozuk koru niteliğindedir. Bu müdürlük bünyesinde 10 adet Orman İşletme Şefliği bulunmaktadır. Bu çalışmaya konu olan alan ise Ören Orman İşletme Şefliğidir. Ören İşletme Şefliği, $39^{\circ} 0^{\prime} 0.25^{\prime \prime}$ ve $39^{\circ} 10^{\prime} 26.60^{\prime \prime}$ kuzey enlemleri ile $29^{\circ} 40^{\prime} 39.90^{\prime \prime}$ ve $29^{\circ} 55^{\prime}$ 24.00" doğu boylamları arasında yer almaktadır (Şekil 3). Ören Orman İşletme Şefliği toplamda 23.780 ha alanı kapsamaktadır. Bunun 13.759 ha'lık kısmı ise ormanlık alanlarla kaplıdır. Geriye kalanların 38 ha'ı mera alanı, 5 ha'ı mezarlık, 1.068 ha'ı orman toprağı, 2 ha'ı su yüzeyi, 224 ha'ı iskân bulunan alanlar ve 8.684 ha'ı ise ziraat alanlarıdır.



Şekil 3. Çalışma alanının coğrafi konumu 
Ören Orman İşletme Şefliğine ait verilere (bölgenin meşcere haritası, yerleşim yerleri, yolları vb.) vektör formatta ayrıca bu bölgede 1997 - 2018 yılları arasında gerçekleşen 27 adet yangın bilgisine yazılı formatta Kütahya Orman Bölge Müdürlüğünden ulaşılmıştır. Eğim ve bakı haritaları ile görülebilirlik analizinin elde edilebilmesi için kullanılan $15 \mathrm{~m}$ çözünürlüklü Sayısal Yükseklik Modeli (DEM) verisi NASA EARTHDATA veritabanından elde edilmiştir.

\subsection{Yöntem}

Bu çalışmada kullanılan temel yöntem ağırlıklı çakıştırma ve görülebilirlik analizidir. Ağırıklı çakıştırmada girdi olarak sadece değerleri belli olan raster veriler kullanılabilmektedir. Sonrasında her bir katman içindeki öznitelikler amaca göre, en uygundan en az uygun olana doğru sıralanır. Sonrasında ise, en uygun olan sınıfa en yüksek değer verilerek puanlar atanır. Çalışmada hiçbir şekilde uygun görülmeyen sınıflara ise en düşük ağırlık puanı atanmalıdır. Bu çalışmada 1-9 arası bir puanlama skalası kullanılmış, 9 "en uygun" olacak şekilde puanlama gerçekleştirilmiştir. Kullanılması uygun olamayan veriler ise kısıtlar kapsamında değerlendirilerek çalışma alanından elenmiştir. Belirlenen kısıtlar ormanlık alanları içermeyen mera alanları, mezarlıklar, orman toprakları, su yüzeyleri, iskân bulunan alanlar ve ziraat alanlarıdır.

Bu çalışmada analiz kapsamında kullanılan katmanlar aşağıda verilmiştir:

- Ağaç türleri risk sınıfları (Meşcere)

- Yerleşim yerleri

- Eğim

- Bakı

- Yollar (Orman yolları, Köy yolları, TCK yolları)

- Kuru dereler

- Yangın kuleleri

- 1997 - 2018 yılları arasında bölgede gerçekleşen 27 adet yangının bilgileri

$\mathrm{Bu}$ verileri içeren sayısal haritaların, ArcGIS 10.6 CBS yazılımı kullanılarak işlenmesi ile orman yangını risk haritası oluşturulmuştur. Yazılım içerisinde ise tampon bölge analizi, 3D analizi ve ağırıklı çakıştırma araçları ile görülebilirlik analizinden faydalanılmıştır. Kullanılan yöntem ve yapılan işlemler Şekil 4'de özetlenmiştir. 


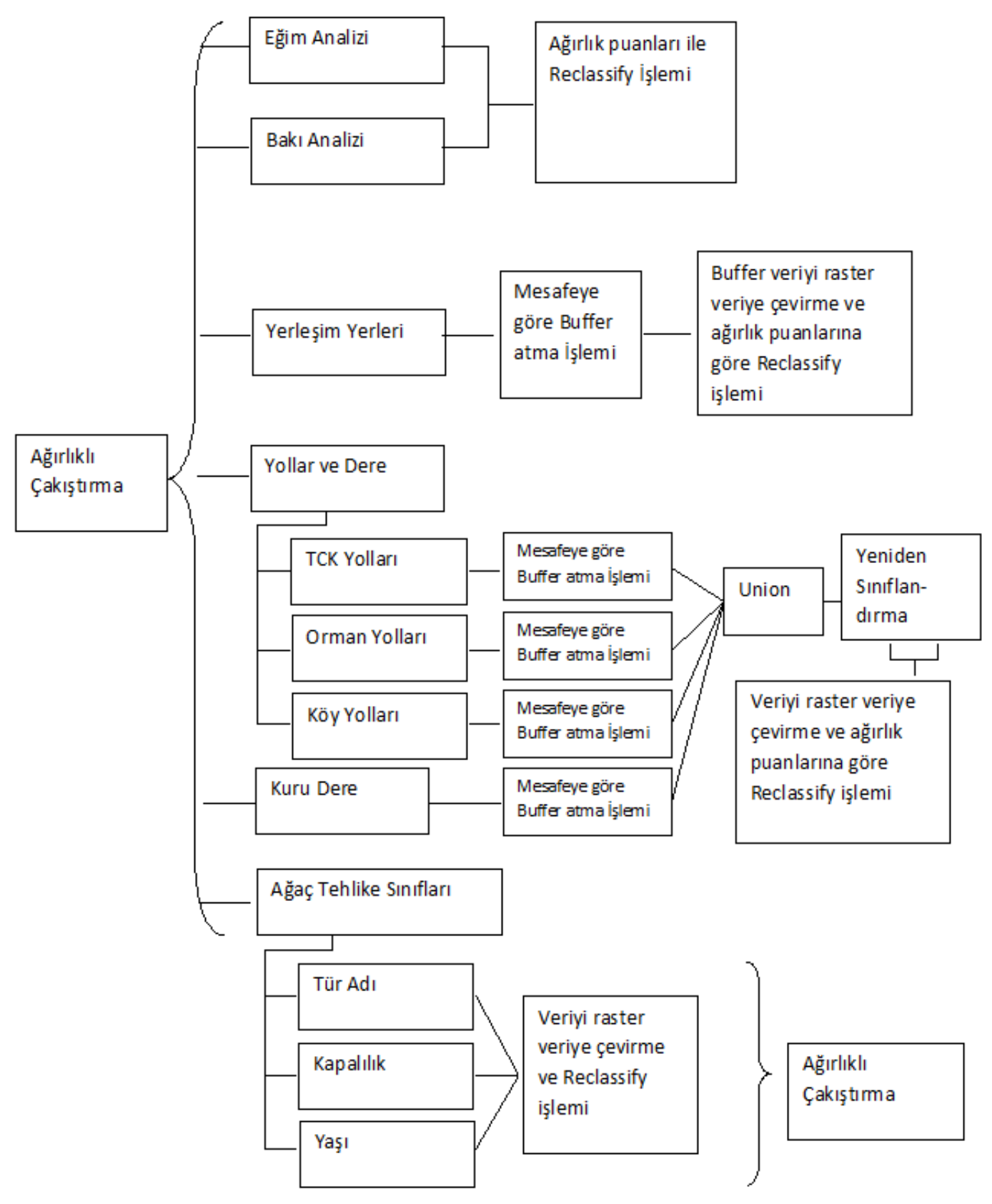

Şekil 4. Kullanılan yöntem ve yapılan işlemler

\section{3. ÇALIŞMA BULGULARI}

\subsection{Ağaç tehlike sınıflarının oluşturulması}

Ören Orman İşletme Şefliği yaklaşık $181 \mathrm{~km}^{2}$, lik bir alana yayılmaktadır. Ormanlar ardıç, karaçam ve makilerden (diğer yapraklılar) oluşmaktadır. Toplam alanın \%57'si ormanlar ile kaplıdır. Bu bölgede bulunan en yaygın türler ardıç ve karaçamdır.

Ağaç tehlike sınıfları, orman meşcere haritasından (Şekil 5) yararlanılarak, ağaç özelliklerinin ağırlıklı olarak çakıştırıması ile belirlenmiştir. Ağaç tehlike sınıfları belirlenirken, meşcereye ait üç özellik ele alınmıştır. Bunlar ağaç tür adı, ağaç kapalıı̆̆ı ve ağaç yaşıdır. Ağırık yüzdeleri dikkate alındığında ağacın türü yangın riski açısından ön plana çıkmaktadır. Ağacın kapalılığı, ormanda bulunan ağaçların sıklık derecesini belirtmektedir. Ormanlık bir bölgenin 
ağaç yoğunluğu (sıklığı) ne kadar çoksa yangın riski de o derece yüksektir. Aynı zamanda gençleştirme sahaları da yangın riskini arttırmaktadır (Orman Genel Müdürlüğü, 1995). Genç orman sahaları, ağacın yaşı dikkate alındığında en riskli grubu oluşturmaktadır. Ağaç tehlike sınıfları için, ağırlıklı çakıştırma puanları Tablo 1' de yer almaktadır. Analizin gerçekleştirilmesi için kullanılan ağaç tür adları Şekil 6'de, ağaç kapalılıkları Şekil 7'da, ağaç yaşları ise Şekil 8'da gösterilmektedir.

Tablo 1. Ağaç tehlike sınıfları için ağırlık puanları

\begin{tabular}{|c|c|c|c|c|}
\hline $\begin{array}{l}\text { Çakıştırma } \\
\text { Katmanı }\end{array}$ & Ağırlık & Sinıflar & Oranlar & $\begin{array}{l}\text { Yangın } \\
\text { Hassasiyeti }\end{array}$ \\
\hline & & Adı & Risk Derecesi & \\
\hline \multirow{4}{*}{ Ağaç tür adı } & \multirow{4}{*}{$40 \%$} & $\operatorname{Ar}($ Ardıç) & 9 & Çok fazla \\
\hline & & Çk (Karaçam) & 9 & Çok fazla \\
\hline & & Bozuk ormanlar & 7 & Fazla \\
\hline & & Dy (Diğer Yapraklılar-Maki) & 6 & Fazla \\
\hline & & Kapalılık Derecesi & Risk Derecesi & \\
\hline \multirow{4}{*}{ Ağaç kapalıı̆̆ı } & \multirow{4}{*}{$30 \%$} & 0 (Genç dikim sahaları) & 9 & Çok fazla \\
\hline & & 1 (\%40 kapalılık) & 7 & Fazla \\
\hline & & 2 (\% 40-\%70 kapalılı) & 8 & Çok fazla \\
\hline & & 3 ( > \% 70 kapalıık) & 9 & Çok fazla \\
\hline & & Yaşı & Risk Derecesi & \\
\hline \multirow{5}{*}{ Ağaç yaşı } & \multirow{5}{*}{$30 \%$} & $\mathrm{~A}$ (0-8 yaş) & 9 & Çok fazla \\
\hline & & $\mathrm{B}$ (8-20 yaş) & 8 & Çok fazla \\
\hline & & C (20-36 yaş) & 7 & Fazla \\
\hline & & $\mathrm{D}$ ( > 37 yaş) & 6 & Fazla \\
\hline & & $\mathrm{K}$ (Karışık-100-120 yaş) & 7 & Fazla \\
\hline
\end{tabular}

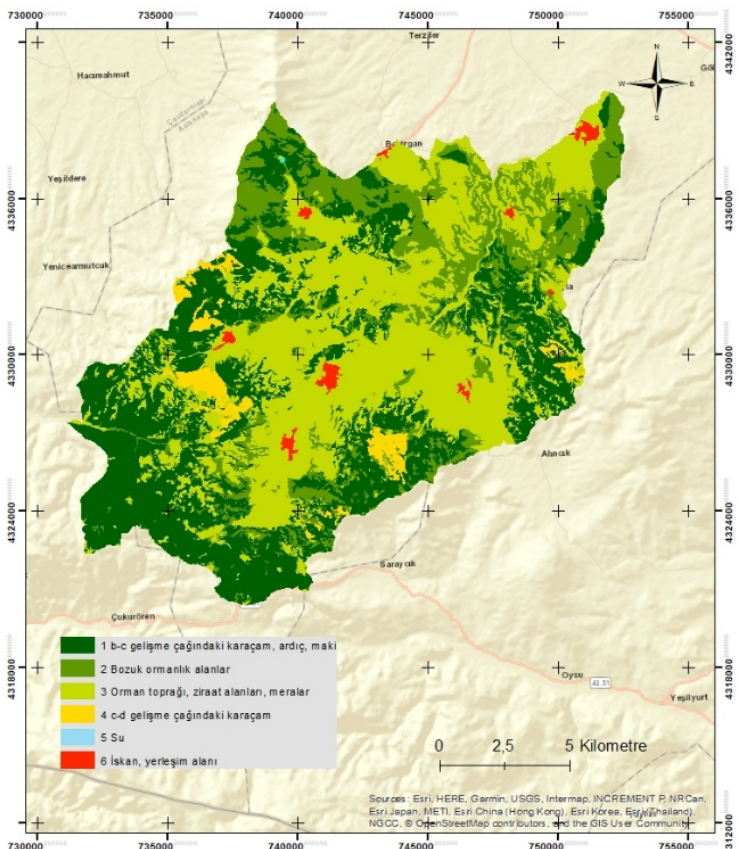

Şekil 5. Ören Orman İşletme Şefliği Meşcere Haritası

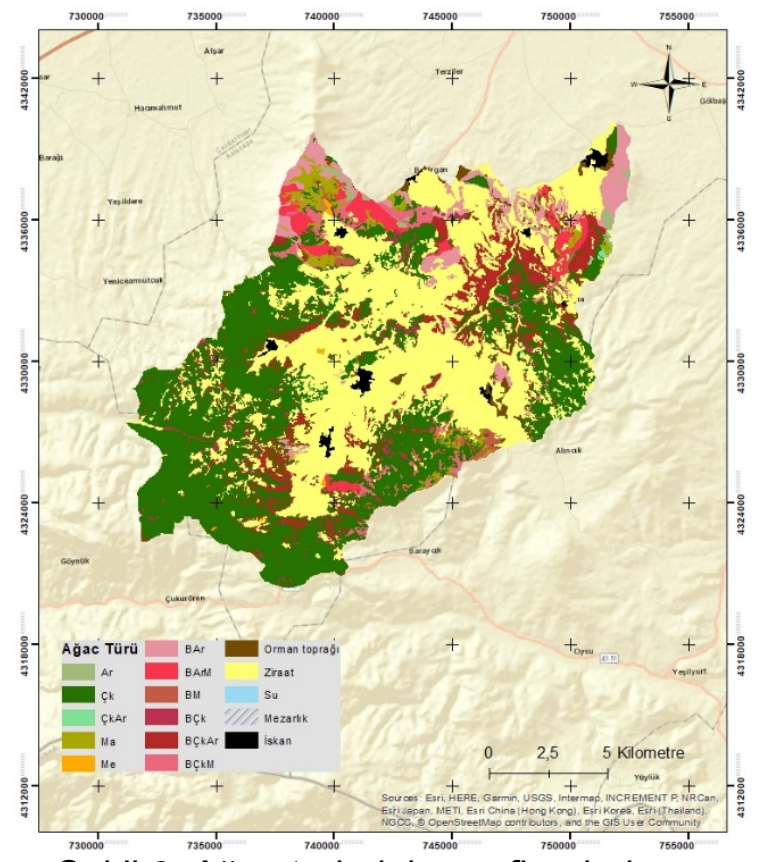

Şekil 6. Ağaç türlerinin sınıflandırılması 




Şekil 7. Ağaç kapalılığının sınıflandırılması

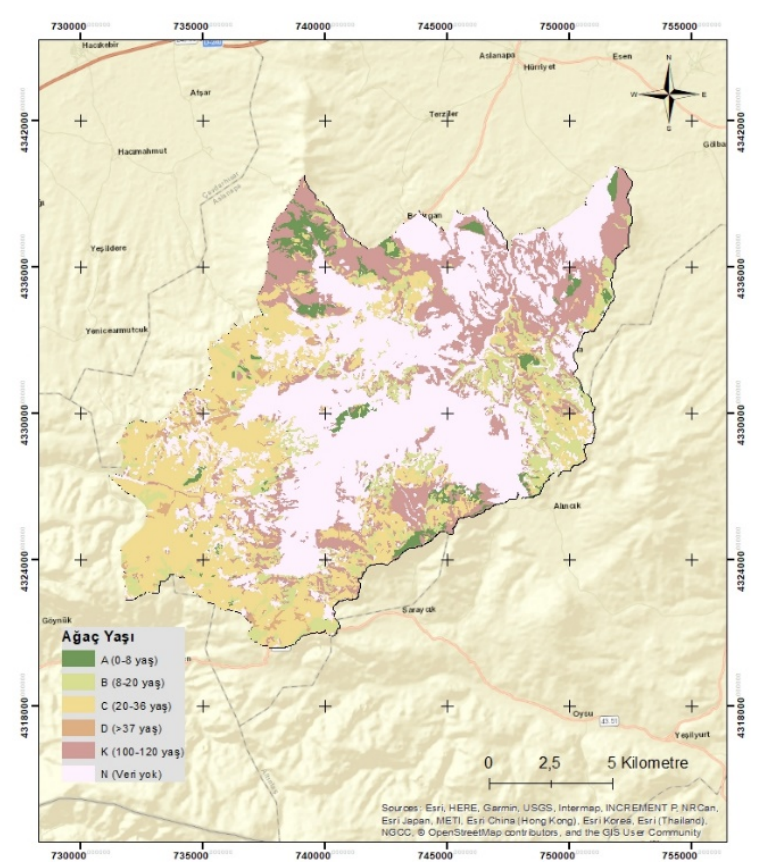

Şekil 8. Ağaç yaşına göre yapılan sınıflandırma

Tablo 1' de verilen ağırlık puanlarına göre yeniden sınıflandırımış meşcere haritaları ise Şekil 9, Şekil 10 ve Şekil 11'de gösterilmektedir.

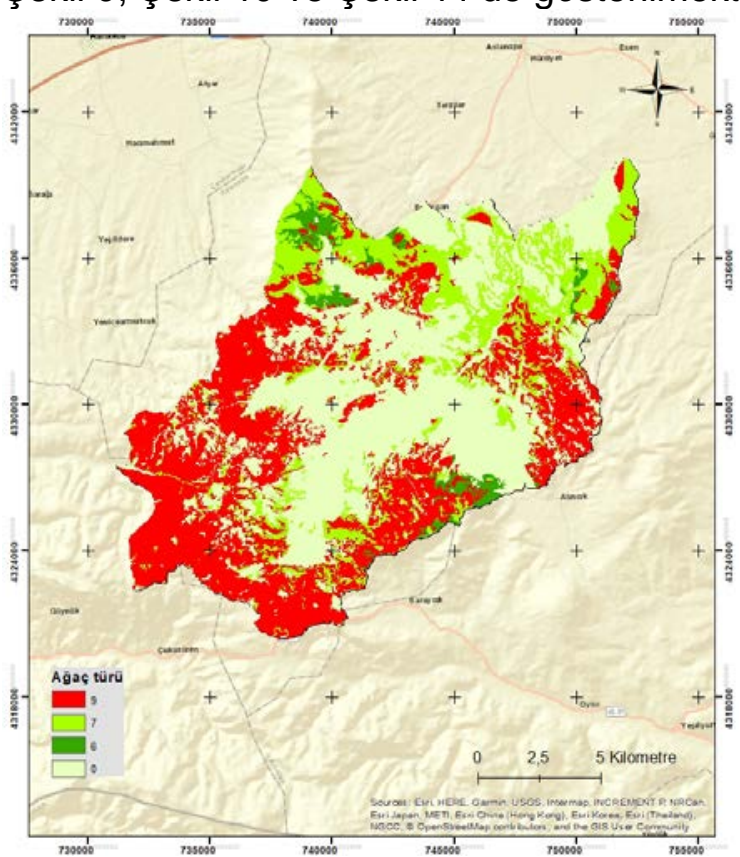

Şekil 9. Ağaç türlerinin ağırlık puanları ile yeniden sınıflandırılması

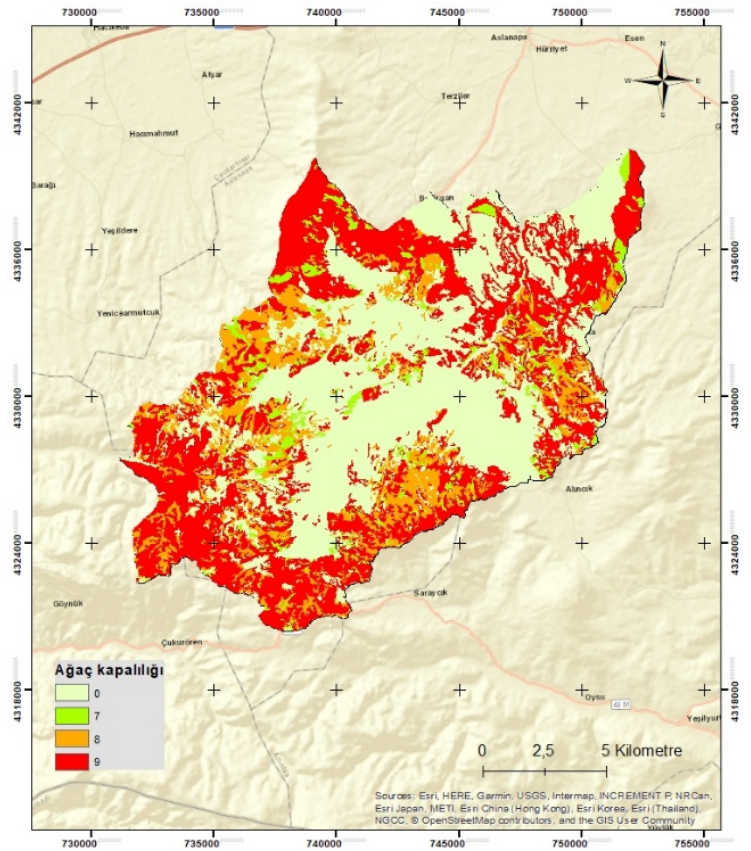

Şekil 10. Ağaç kapalıı̆ının ağırlık puanları ile yeniden sınıflandırılması 


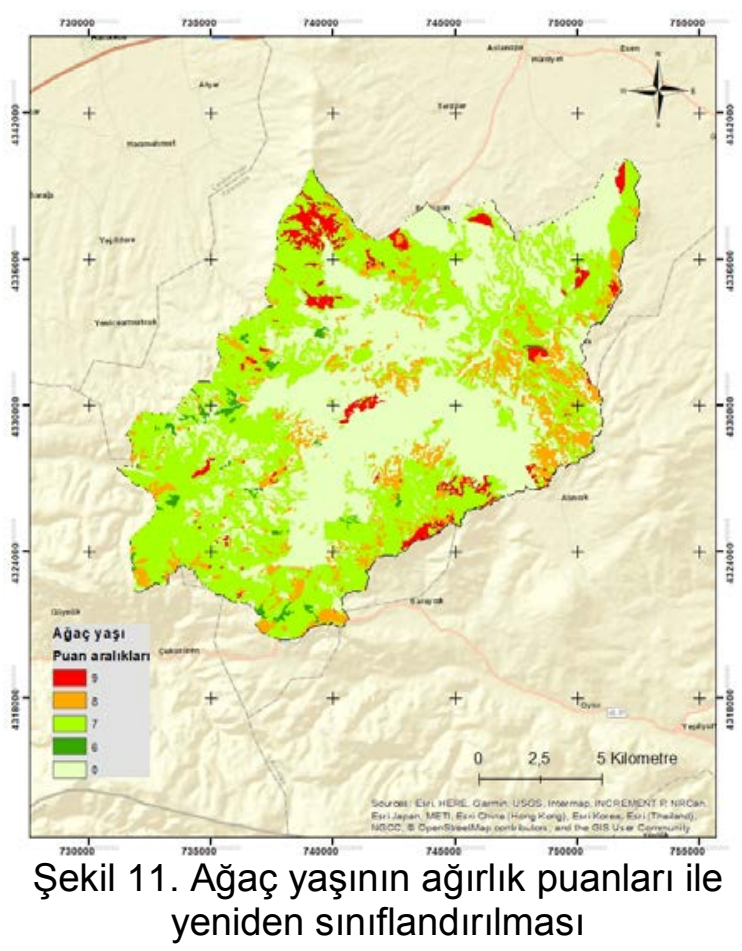

Bu verilerin ağılıklı çakıştırılması ile oluşan Ören Orman İşletme Şefliği için ağaç tehlike sınıfları haritası Şekil 12'de verilmiştir. Aynı zamanda bu harita Ören Orman İşletme Şefliği orman yangınları risk haritası için kullanılacak veriyi sağlamaktadır. 


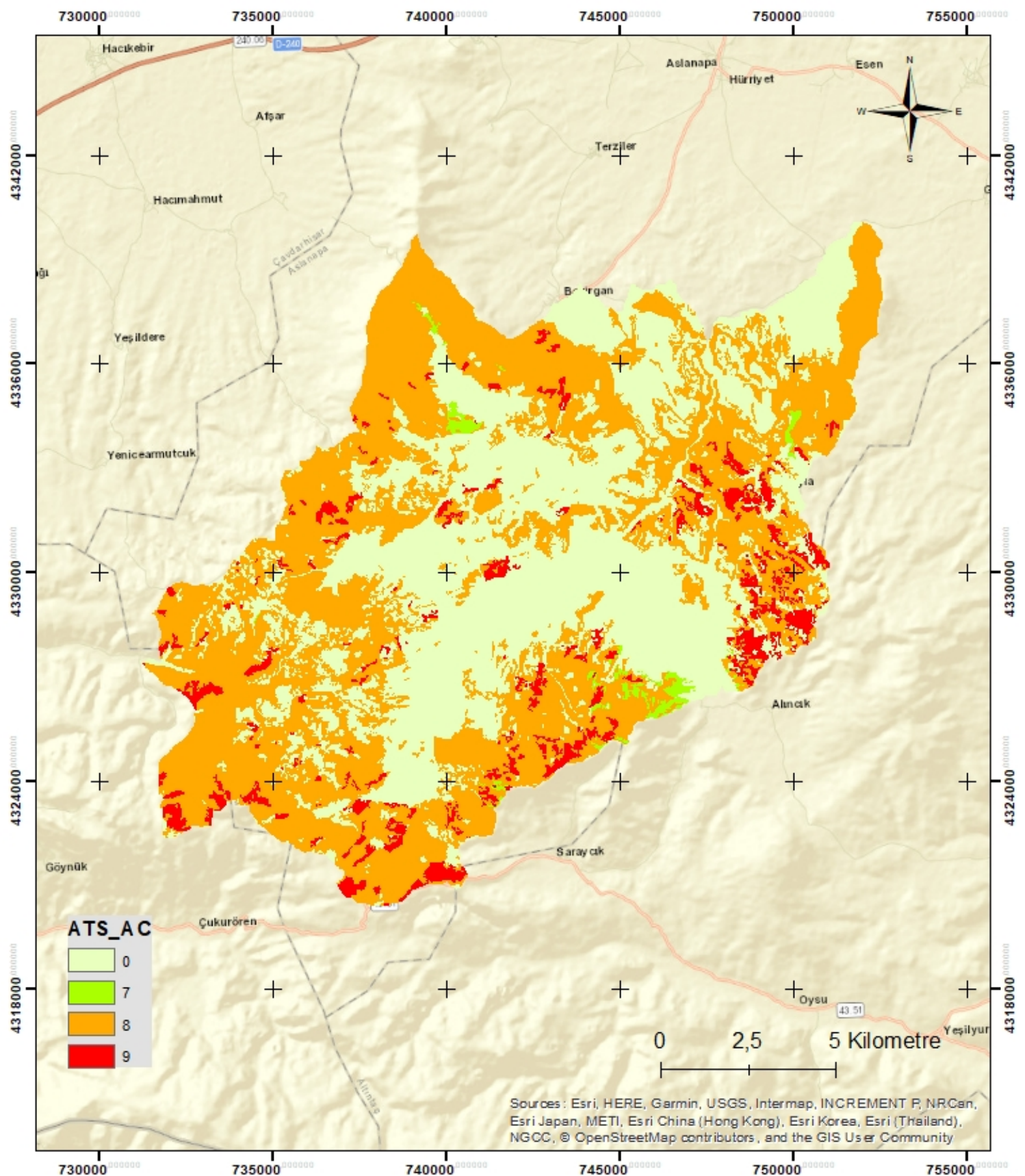

Şekil 12. Ağaç tehlike sınıfları haritası

\section{2. Ören Orman İşletme Şefliği orman yangını risk haritasının oluşturulması}

\subsubsection{Topoğrafya}

Topoğrafya yangınların oluşması ve yayılması (eğim, bakı) açısından çok önemli bir faktördür. Eğim, oluşan yangının hareketinde, sıçramasında ve yangına müdahalede dikkate alınmaktadır. Güney, güneybatı ve batıya bakan alanlar ise orman yangınları için ayrıca risk oluşturan faktörlerdendir. Çalışılan bölgenin deniz seviyesinden yüksekliği 0 ile 196 m. 
arasında değişmektedir (Şekil 13). DEM'den türetilerek oluşturulmuş eğim ve bakı haritaları Şekil 14 ve Şekil 15'de gösterilmektedir.
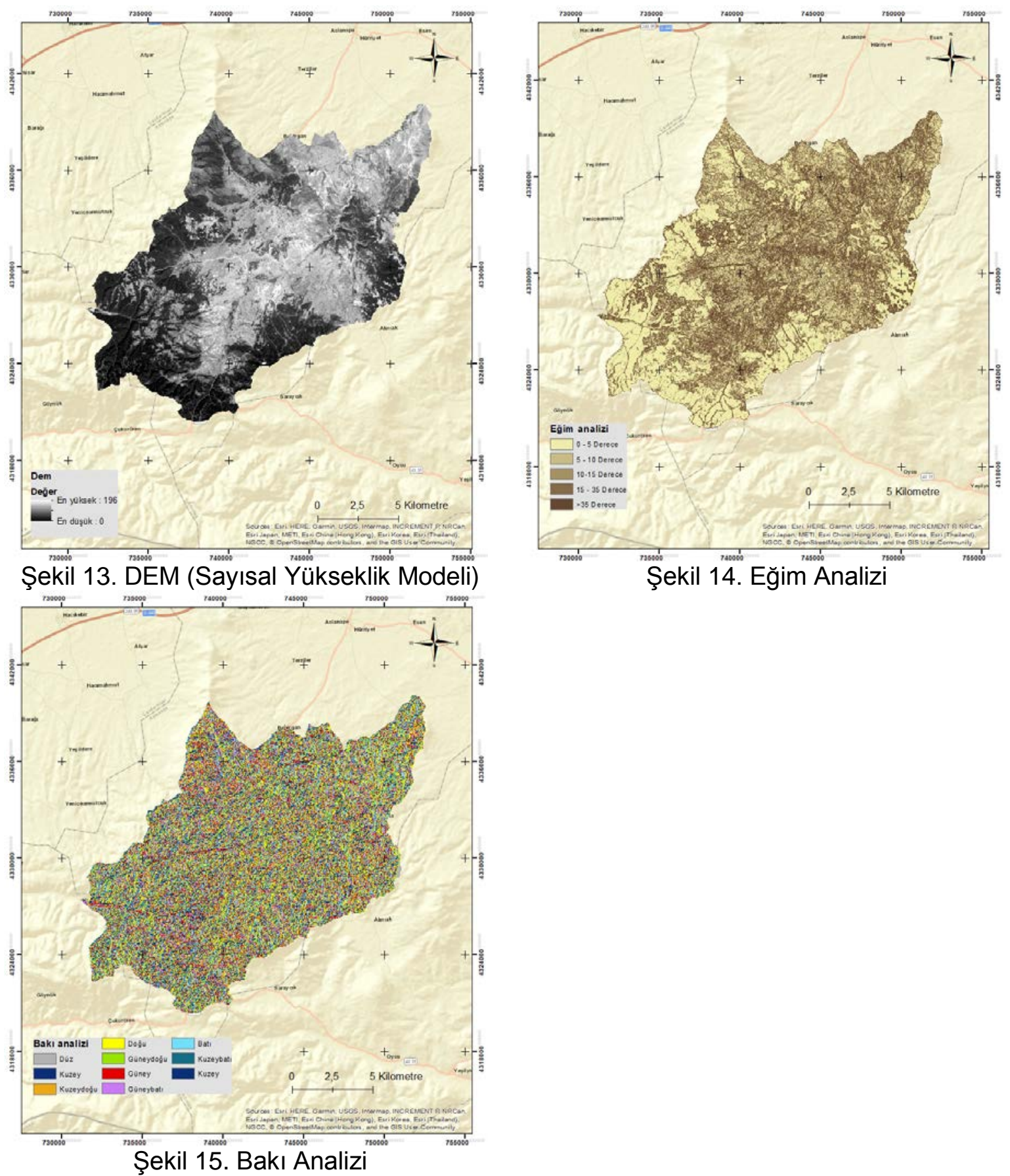

\subsubsection{Yerleşim yerleri, yollar ve kuru dereler}

Yerleşim yerleri ve yollar orman yangınlarının oluşmasında büyük önem taşımaktadır. Ören Orman İşletme Şefliğinde 11 adet yerleşim yeri (Şekil 16) ile bu bölgede ulaşımı sağlayan Türkiye Cumhuriyeti Karayolları (TCK), orman yolları ve köy yolları (Şekil 17) bulunmaktadır. Buralarda insan faaliyetinin yoğun olması nedeni ile risk artmaktadır. Yine bu alanda bulunan kuru dereler de içerdikleri kuru madde yoğunluğu nedeni ile yangın riski açısından önem arz etmektedir ve Şekil 18'de gösterilmektedir (Orman Genel Müdürlüğü, 1995). 

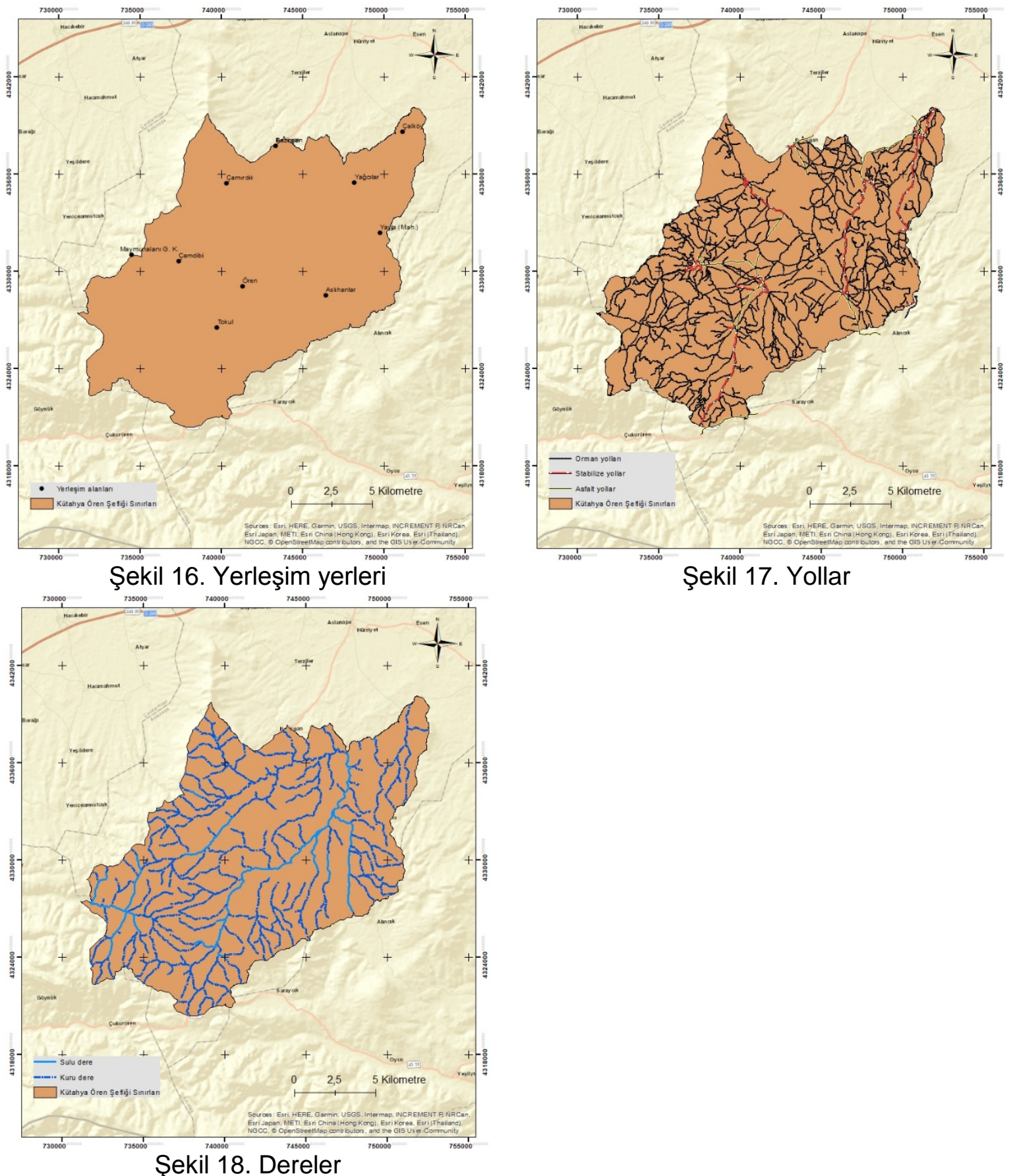


\subsubsection{Ağırlıklı çakıştırma}

Ağırlıklı çakıştırma işlemine başlayabilmek için tüm katmanlar

Tablo 2'de gösterilen ağırlık puanlarına göre yeniden sınıflandırılmışlardır.

Tablo 2. Orman yangınları risk haritalaması için ağırlık puanları ve oranları

\begin{tabular}{|c|c|c|c|c|}
\hline $\begin{array}{l}\text { Çakıştırma } \\
\text { Katmanı }\end{array}$ & Ağırlık & Sınıflar & Oranlar & $\begin{array}{l}\text { Yangın } \\
\text { Hassasiyeti }\end{array}$ \\
\hline \multirow{5}{*}{ Eğim } & \multirow{5}{*}{$15 \%$} & $>35$ Derece & 9 & Çok fazla \\
\hline & & 35 - 15 Derece & 8 & Çok fazla \\
\hline & & 15 - 10 Derece & 6 & Fazla \\
\hline & & 10 - 5 Derece & 4 & Orta \\
\hline & & 0 - 5 Derece & 2 & Düşük \\
\hline \multirow{9}{*}{ Bakı } & \multirow{9}{*}{$15 \%$} & Güney & 9 & Çok fazla \\
\hline & & Güney Batı & 9 & Çok fazla \\
\hline & & Güney Doğu & 8 & Çok fazla \\
\hline & & Kuzey Batı & 4 & Orta \\
\hline & & Kuzey Doğu & 4 & Orta \\
\hline & & Kuzey & 2 & Düşük \\
\hline & & Doğu & 6 & Fazla \\
\hline & & Batı & 6 & Fazla \\
\hline & & Düz & 5 & Orta \\
\hline \multirow{6}{*}{ Yollar } & \multirow{6}{*}{$20 \%$} & $0-50 \mathrm{~m}$ & 9 & Çok fazla \\
\hline & & $50-100 \mathrm{~m}$ & 8 & Çok fazla \\
\hline & & $100-200 \mathrm{~m}$ & 6 & Fazla \\
\hline & & $200-300 \mathrm{~m}$ & 4 & Orta \\
\hline & & $300-400 \mathrm{~m}$ & 2 & Düşük \\
\hline & & $>400 \mathrm{~m}$ & 1 & Düşük \\
\hline \multirow{6}{*}{ Kuru Dereler } & \multirow{6}{*}{$10 \%$} & $0-50 \mathrm{~m}$ & 9 & Çok fazla \\
\hline & & $50-100 \mathrm{~m}$ & 8 & Çok fazla \\
\hline & & $100-200 \mathrm{~m}$ & 6 & Fazla \\
\hline & & $200-300 \mathrm{~m}$ & 4 & Orta \\
\hline & & $300-400 \mathrm{~m}$ & 2 & Düşük \\
\hline & & $>400 \mathrm{~m}$ & 1 & Düşük \\
\hline \multirow{9}{*}{$\begin{array}{l}\text { Yerleşim } \\
\text { Alanları }\end{array}$} & \multirow{9}{*}{$20 \%$} & $0-50 \mathrm{~m}$ & 9 & Çok fazla \\
\hline & & $50-100 \mathrm{~m}$ & 8 & Çok fazla \\
\hline & & $100-200 \mathrm{~m}$ & 7 & Fazla \\
\hline & & $200-300 \mathrm{~m}$ & 6 & Fazla \\
\hline & & $300-400 \mathrm{~m}$ & 5 & Orta \\
\hline & & $400-500 \mathrm{~m}$ & 4 & Orta \\
\hline & & $500-1000 \mathrm{~m}$ & 3 & Düşük \\
\hline & & $1000-1500 \mathrm{~m}$ & 2 & Düşük \\
\hline & & $>1500 \mathrm{~m}$ & 1 & Düşük \\
\hline \multirow{4}{*}{$\begin{array}{l}\text { Ağaç Tehlike } \\
\text { Sınıları }\end{array}$} & \multirow{4}{*}{$20 \%$} & \multirow{4}{*}{$\begin{array}{l}\text { Tablo 1' de belirlenen esaslara } \\
\text { göre oluşturulmuştur. }\end{array}$} & 9 & Çok fazla \\
\hline & & & 8 & Çok fazla \\
\hline & & & 7 & Fazla \\
\hline & & & 0 & Kısıt alanları \\
\hline
\end{tabular}


Tehlike dereceleri ile yeniden sınıflandırılmış bakı analizine göre; güney ve güney batıya bakan alanlar orman yangını açısından en riskli alanlardır ve kırmızı renk ile gösterilmiştir (Şekil 19). Eğim analizi de yeniden sınıflandırıldığında aldığı değerler sonucu oluşturulan tematik harita Şekil 20'de gösterilmektedir. Yerleşim yerlerinin etrafına buffer atılarak, ağırlık puanları ile yeniden sınıflandırılmasıyla oluşan yerleşim yerleri risk sınıfları haritası Şekil 21'de yer almaktadır. Yollar ve kuru dereler ağırlıkı çakıştırmada kullanılmak üzere yeniden sınıflandırma işlemine tabi tutulmuştur. Buna göre oluşturulan haritlar Şekil 22 ve Şekil 23'de gösterilmektedir. Ağaç tehlike sınıfları haritası önceden hazırlanmış olup Şekil 12'de verilmiştir.

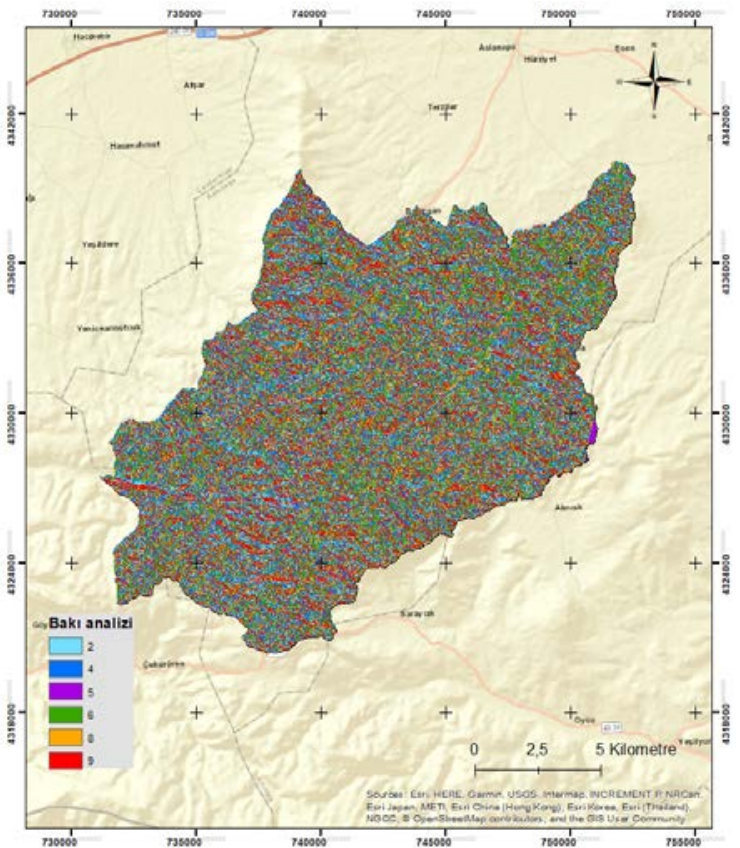

Şekil 19. Yeniden sınıflandırılmış bakı

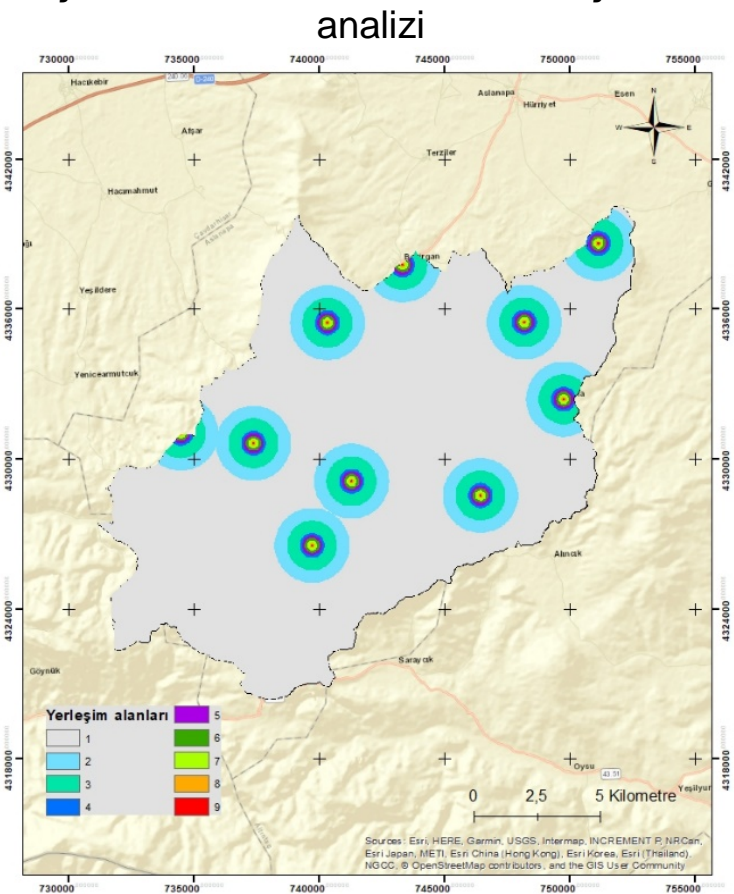

Şekil 21. Risk sınıflarına göre yerleşim alanlarına olan mesafe

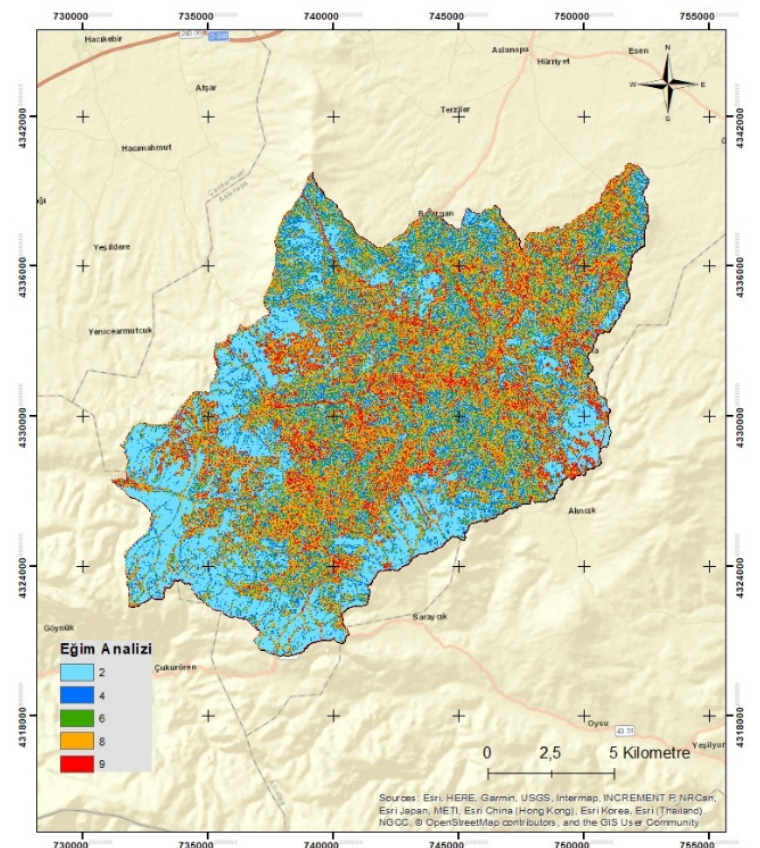

Şekil 20. Yeniden sınıflandırılmış eğim

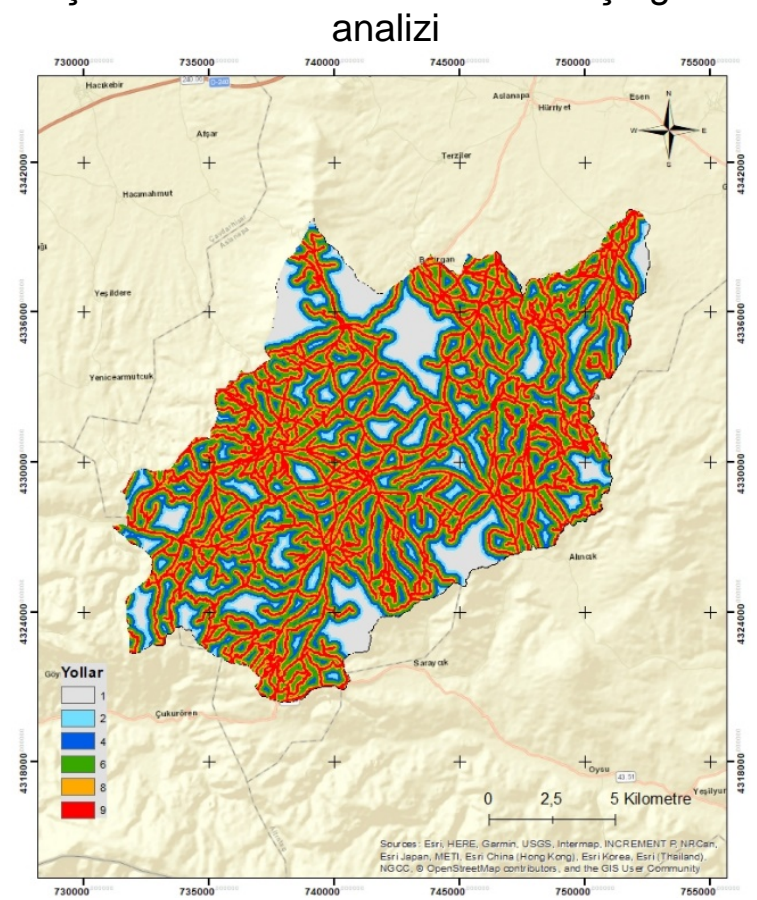

Şekil 22. Risk sınıflarına göre yollara olan mesafe 


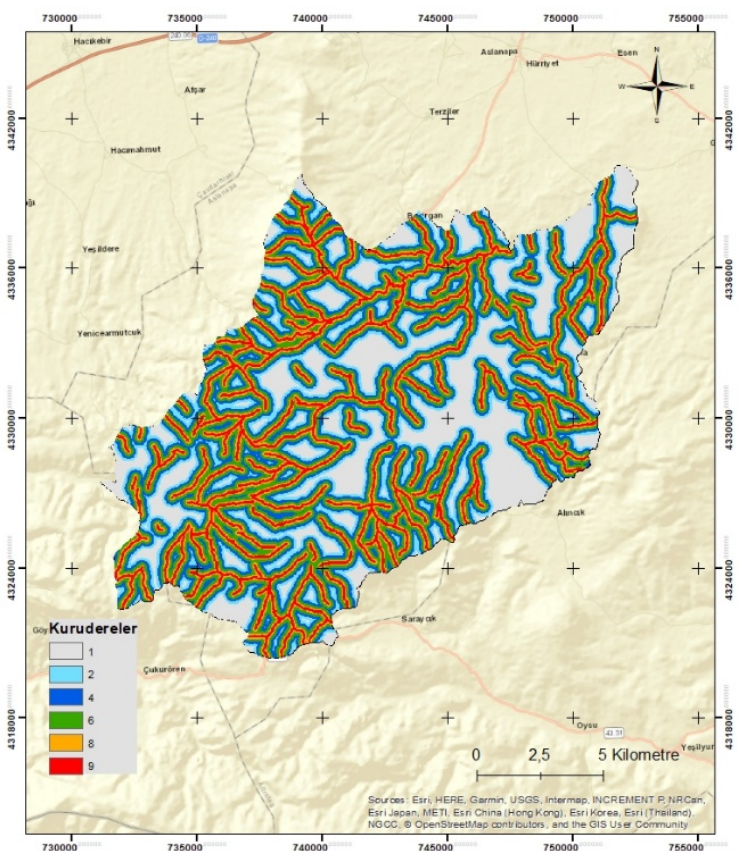

Şekil 23. Risk sınıflarına göre kuru derelere olan mesafe

Toplamda 6 katmanın belirlenen ağırlık puanları ile ağırlıklı çakıştırılması sonucu oluşturulan sonuç haritası Şekil 24'da yer almaktadır. 


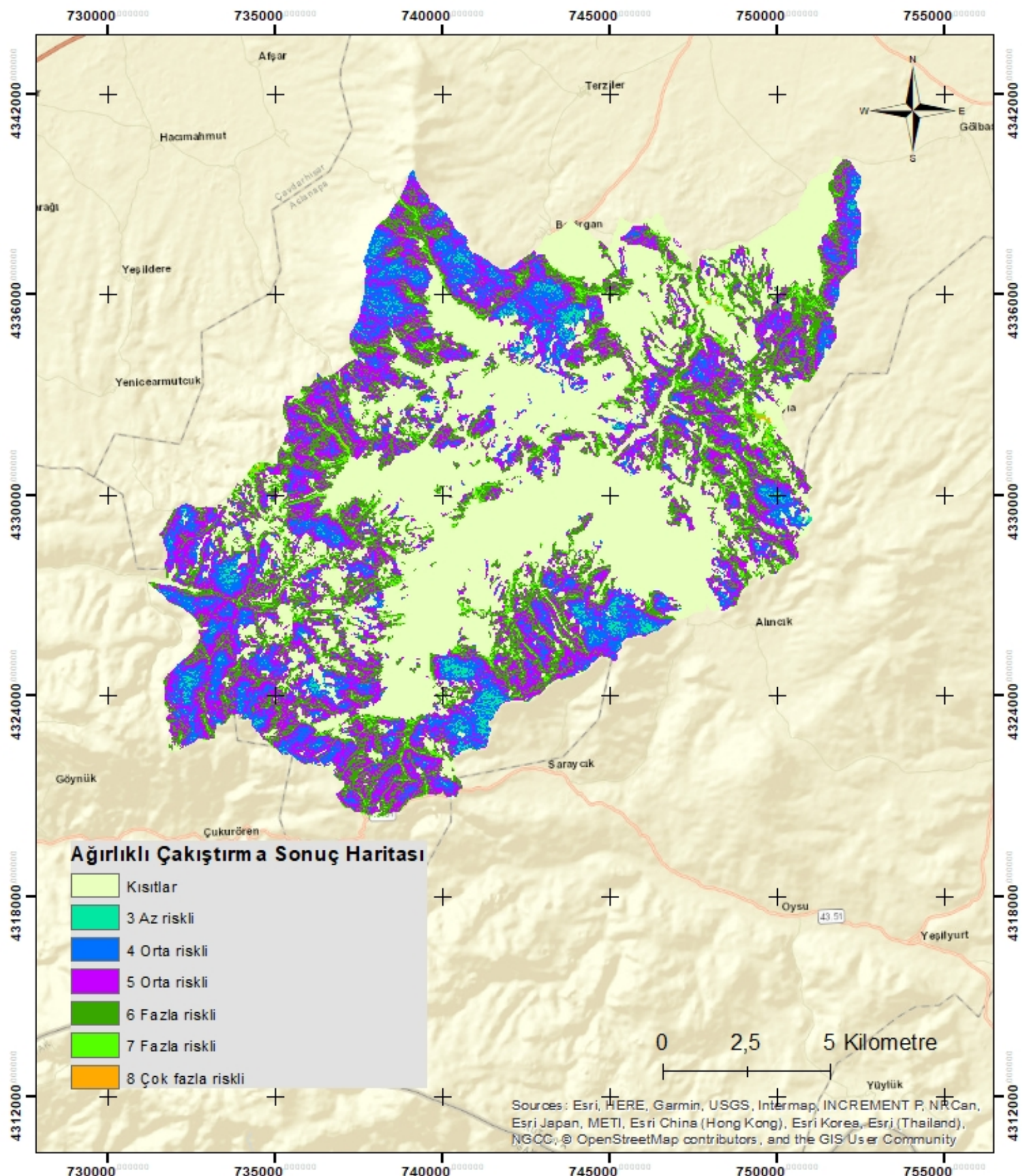

Şekil 24. Kütahya - Ören Orman İşletme Şefliği Orman Yangını Risk Haritası

3.3. Ören Orman İşletme Şefliği için yangın kuleleri görülebilirlik analizinin gerçekleştirilmesi

Görülebilirliğin belirlenebilmesi için çalışma alanında ve bu alanın etrafında yer alan 19 adet yangın kulesi (Şekil 25) ile bu kulelerin yükseklikleri göz önüne alınarak DEM verisi ile görülebilirlik analizi yapılmıştır. Bu analiz çalışma alanının etrafındaki yangın kulelerinden sahanın ne kadarının görüldüğünü göstermek için gerçekleştirilmiştir. 




Şekil 25. Kütahya ili - Ören, Emet ve Kütahya Orman İşletme Şefliği yangın kuleleri

Analiz sonucunda Ören Orman İşletmesi yangın kulelerinden bölgenin görülebilen kısmı yeşil, görülemeyen kısmı ise pembe renk ile gösterilmiştir (Şekil 26). Oluşturulan haritaya göre alanın \%82,8'i bölgedeki yangın kulelerince görülebilirken, \%17,2 sinin bu kulelerin görüş alanına girmediği dikkat çekmektedir. 


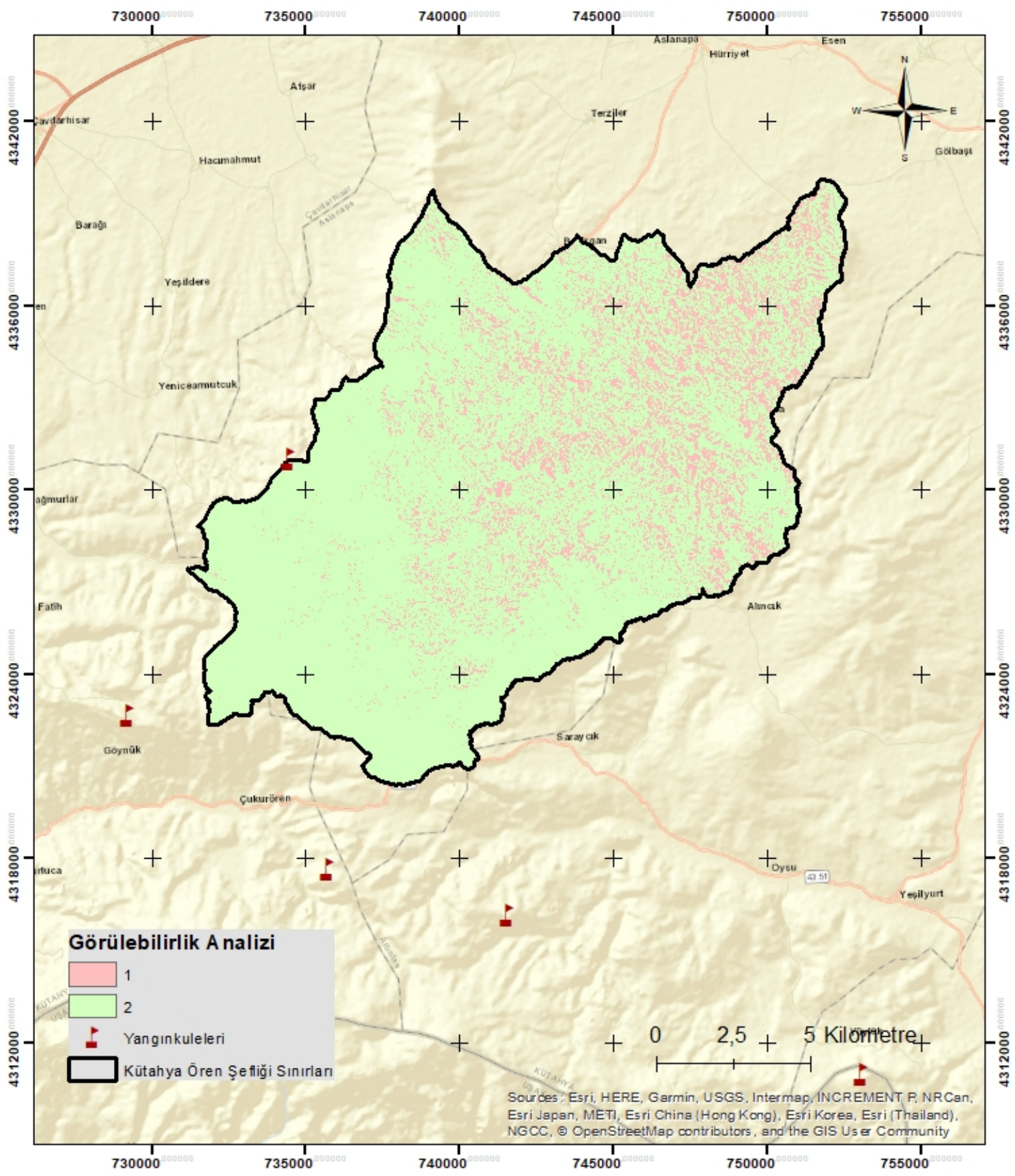

Şekil 26. Görülebilirlik analizi sonuç haritası

\section{TARTIŞMA VE SONUÇ}

Bu çalışmada Kütahya Orman İşletme Müdürlüğü, Ören İşletme Şefliğine ait eğim, bakı, ağaç tehlike sınıfları ile yerleşim yerleri, yollar ve kuru derelere olan mesafeler analiz edilerek belirlenen, bu faktörlere bağlı olarak oluşturulan Ören Orman İşletme Şefliği yangın risk haritası ortaya konulmuştur.

Ören orman işletme şefliği için orman yangınları riski 9 puan üzerinden değerlendirilmiştir. Bölgenin orman yangını riskinin büyük oranda 5 puan (orta) olduğu saptanmıştır. Bu alanlar 
ise genellikle orman yollarının ve kuru derelerin etrafında bulunmaktadır. Şüphesiz ki sonuç haritasının oluşturulmasında ağaç tehlike sınıflarının da büyük rolü vardır.

Kütahya Ören Orman İşletme Şefliği alanı için oluşturulan yangın risk haritasına göre alanlarının dağılımı şu şekildedir:

- \%36,86'sı yangın potansiyeli yönünden çok riskli,

- $\% 60,39$ 'u yangın potansiyeli yönünden orta riskli,

- $\quad \% 2,76$ 'sı yangın potansiyeli yönünden az riskli alanlardır.

Yapılan analizler değerlendirildiğinde ağaç yaşının düşük ve kapalılığın az olduğu alanlarda yangın riskinin 4-5 orta riskli veya daha düşük olduğu, artan ağaç yaşı ve kapalılık ile birlikte yangın riskinin arttığı görülmektedir. Bozuk ormanlarda yangın riskinin bozuk olmayan karaçam ve ardıç meşcerelerine oranla daha yüksek olduğu belirlenmiştir. Meşçere yapısı, ağaç türü ve kapalılık oranı yangın riskinde önemli bir faktör olarak dikkat çekmektedir. Ağırlıklı çakıştırma ile oluşturulan yangın risk haritası incelendiğinde kapalılık oranının artması yangın riskini artıran bir faktör olarak göze çarpmaktadır. Çalışma alanında yangın riskinin daha yüksek olduğu kısımların yerleşim alanlarına yakın olduğu görülmektedir. Yol ağı özellikle insan kaynaklı yangın riskini artıran bir faktördür. Yol ağının sıklaştığı ormanlık alanlarda riskin arttığı değerlendirilmektedir. Kuru derelerdeki çalılık alanlar ile diri örtü varlığı, insan faktörü ile birlikte değerlendirildiğinde yangın riskinin buralarda da arttığı söylenebilir. Çalışma alanında 11 adet yerleşim yeri bulunmaktadır. Bu yerleşim merkezi alanlarından Tokul, Ören, Aslıhanlar ve Çalköy ormanlık alanlara olan uzaklığı nedeniyle orman alanları için büyük risk oluşturmayan alanlardır. Diğer yerleşim alanları ise orman alanlarına bitişik veya çok yakın olması nedeniyle yangın riskini artıran bir faktör olarak değerlendirilmiştir. Yangın gözetleme kulelerinin konumuna ve yüksekliği temel alınarak yapılan görülebilirlik analizi sonucunda oluşturulan haritaya göre alanın \%82,8'inin bölgedeki yangın gözetleme kuleleri tarafından görülebilir olması olumlu bir özellik olarak değerlendirilmiştir. Ayrıca orman alanının tamamı görülebilir olmasa da meydana gelebilecek bir yangında duman tespiti için \%82,8 görülebilirlik oranının oldukça yeterli olduğu değerlendirilmektedir.

Özellikle yangın potansiyeli yüksek ormanlık alanlarda bu yöntemin kullanılması yangınla mücadele çalışmalarında yüksek oranda başarı sağlayacaktır. Bu yöntem ile belirlenen yanıcı madde özelliklerine göre yangın potansiyeli yüksek alanların yoğunlaştığı yerler belirlenerek yangın gözetleme sistemleri ile yangın sezonlarında takip edilmelidir. Olası yangın durumlarında yanıcı madde özelliklerine göre yangın potansiyeli yüksek alanların yoğunlaştığı yerlerde yangın daha çabuk yayılacak ve daha şiddetli olacaktır. Bu sebeple bu alanların yoğunlaştığı yerlere arazözlerle müdahale edebilmeyi sağlayabilecek şekilde yangın emniyet yol ve şeritleri yapılmalıdır. Yine bu alanların yoğunlaştığı yerlerin çevresine su söndürme araçlarının (arazöz-helikopter) takviye yapabileceği yangın havuzları planlanmalıdır.

\section{BİLGILENDIRME}

Kütahya Ören Orman İşletme Şefliği haritalarının temininde yardımlarından dolayı Kütahya Orman Bölge Müdürlüğü, Ören Orman İşletme Şefi Murat Yıldırım' a ve Kastamonu Üniversitesi, Orman Fakültesi bünyesinde görev yapan Doç. Dr. Burak Arıcak'a katkılarından dolayı teşekkür ederiz. 


\section{KAYNAKLAR}

Asri, G., Çorumluoğlu, Ö., ve Özdemir, E. (2017, 25-28 Mart 2015). CBS destekli Orman Yangını Risk Dağılım Analizi; Antalya Örneği. Paper presented at the 15. Türkiye HaritaBilimsel ve Teknik Kurultayı, Ankara.

Bailey, R. P. (2001). Forest Fire Prevention And Suppression Guidelines For Industrial Activities. Erişim adresi: Nothwest Territories: https://www.enr.gov.nt.ca/sites/enr/files/industrial_guidelines_forest_fire_prevention_suppres sion.pdf

Bingöl, B. (2017). Coğrafi Bilgi Sistemleri Kullanarak Burdur İli Orman Yangını Risk Alanlarının Belirlenmesi. Turkish Journal of Forest Science, 1(2), 169-182.

Chuvieco, E., ve Salas, J. (1996). Mapping the spatial distribution of forest fire danger using GIS. International Journal of Geographical Information Science, 10(3), 333-345.

Çalışkan, S., ve Boydak, M. (2017). Afforestation of arid and semiarid ecosystems in Turkey. Turkish Journal of Agriculture and Forestry, 41(5), 317-330.

Erten, E., Kurgun, V., ve Musaoglu, N. (2004). Forest fire risk zone mapping from satellite imagery and GIS: a case study. Paper presented at the XXth Congress of the International Society for Photogrammetry and Remote Sensing, Istanbul, Turkey.

Eugenio, F. C., Dos Santos, A. R., Fiedler, N. C., Ribeiro, G. A., da Silva, A. G., Dos Santos, Á. B., Paneto, G. G., ve Schettino, V. R. (2016). Applying GIS to develop a model for forest fire risk: a case study in Espírito Santo, Brazil. Journal of environmental management, 173, 65-71.

Finney, M. A. (2005). The challenge of quantitative risk analysis for wildland fire. Forest Ecology and Management, 211(1-2), 97-108.

İşçi, M. (2018). Orman Yangınları ile Mücadele ve Faaliyetleri 2018 Yılı Değerlendirme Raporu. Erişim adresi: https://muglaobm.ogm.gov.tr/SiteAssets/Lists/Duyurular/NewForm/2018_Yili_Orman_Yanginl ari_Degerlendirme_Raporu.pdf

Jaiswal, R. K., Mukherjee, S., Raju, K. D., ve Saxena, R. (2002). Forest fire risk zone mapping from satellite imagery and GIS. International Journal of Applied Earth Observation and Geoinformation, 4(1), 1-10.

Kavgaci, A., Örtel, E., Torres, I., ve Safford, H. (2016). Early postfire vegetation recovery of Pinus brutia forests: effects of fire severity, prefire stand age, and aspect. Turkish Journal of Agriculture and Forestry, 40(5), 723-736.

Kaysis. (2019). Orman Yangınlarının Önlenmesi ve Söndürülmesinde Uygulama Esasları. Kamu Mevzuat Sistemi. Erişim adresi: https://kms.kaysis.gov.tr/Home/Goster/129296.

Küçük, Ö., ve Bilgili, E. (2007). Yangın Davranışının Coğrafi Bilgi Sistemi (CBS) Yardımıyla Haritalanması: Korudağ Örneği. KSÜ Fen ve Mühendislik Dergisi, 10(2), 64-70.

Küçük, Ö., Bilgili, E., ve Durmaz, B. D. (2005). Yangın Potansiyelinin Belirlenmesinde Yanıcı Madde Haritalarının Önemi. Turkish Journal of Forestry, 1, 104-116.

Massada, A. B., Radeloff, V. C., Stewart, S. I., ve Hawbaker, T. J. (2009). Wildfire risk in the wildland-urban interface: a simulation study in northwestern Wisconsin. Forest Ecology and Management, 258(9), 1990-1999. 
Meddens, A. J., Kolden, C. A., ve Lutz, J. A. (2016). Detecting unburned areas within wildfire perimeters using Landsat and ancillary data across the northwestern United States. Remote Sensing of Environment, 186, 275-285.

Mirzaei, J. (2016). Impacts of two spatially and temporally isolated anthropogenic fire eventson soils of oak-dominated Zagros forests of Iran. Turkish Journal of Agriculture and Forestry, 40(1), 109-119.

Modugno, S., Balzter, H., Cole, B., ve Borrelli, P. (2016). Mapping regional patterns of large forest fires in Wildland-Urban Interface areas in Europe. Journal of environmental management, 172, 112-126.

Nasi, R., Dennis, R., Meijaard, E., Applegate, G., ve Moore, P. (2002). Forest fire and biological diversity. UNASYLVA-FAO-, 36-40.

Navarro, G., Caballero, I., Silva, G., Parra, P.-C., Vázquez, Á., ve Caldeira, R. (2017). Evaluation of forest fire on Madeira Island using Sentinel-2A MSI imagery. International Journal of Applied Earth Observation and Geoinformation, 58, 97-106.

Orman Genel Müdürlüğü. Orman Atlası.

Orman Genel Müdürlüğü. (1995). Orman Yangınlarının Önlenmesi ve Söndürülmesinde Uygulama Esasları.

Özşahin, E. (2014). Forest Fire Susceptibility Analysis Using GIS and AHP: The Case Of Antakya Forestry Operation Directorate.

Patz, J. A., Frumkin, H., Holloway, T., Vimont, D. J., ve Haines, A. (2014). Climate change: challenges and opportunities for global health. Jama, 312(15), 1565-1580.

Peker, H., ve Atılgan, A. (2015). Doğal Bir Enerji Kaynağı Odun: Yanma Özelliği ve Koruma Yöntemleri. Afyon Kocatepe Üniversitesi Fen Ve Mühendislik Bilimleri Dergisi, 15(2), 1-12.

Romero-Calcerrada, R., Novillo, C., Millington, J., ve Gomez-Jimenez, I. (2008). GIS analysis of spatial patterns of human-caused wildfire ignition risk in the SW of Madrid (Central Spain). Landscape Ecology, 23(3), 341-354.

Shafiei, A. B., Akbarinia, M., Jalali, G., ve Hosseini, M. (2010). Forest fire effects in beech dominated mountain forest of Iran. Forest Ecology and Management, 259(11), 2191-2196.

Siachalou, S., Doxani, G., ve Tsakiri-Strati, M. (2009). INTEGRATING remote sensing processing and GIS to fire risk zone mapping: a case study for the Seih-Sou forest of Thessaloniki. Paper presented at the Proceeding of ICC.

Van Wagtendonk, J. W., Root, R. R., ve Key, C. H. (2004). Comparison of AVIRIS and Landsat ETM+ detection capabilities for burn severity. Remote Sensing of Environment, 92(3), 397-408.

White, J. D., Ryan, K. C., Key, C. C., ve Running, S. W. (1996). Remote sensing of forest fire severity and vegetation recovery. International Journal of Wildland Fire, 6(3), 125-136.

Yassemi, S., Dragićević, S., ve Schmidt, M. (2008). Design and implementation of an integrated GIS-based cellular automata model to characterize forest fire behaviour. ecological modelling, 210(1-2), 71-84. 